This item was submitted to Loughborough's Research Repository by the author.

Items in Figshare are protected by copyright, with all rights reserved, unless otherwise indicated.

\title{
Sport policy development in China: Legacies of Beijing's 2008 Summer Olympic Games and 2022 Winter Olympic Games
}

\section{PLEASE CITE THE PUBLISHED VERSION}

https://doi.org/10.1080/24704067.2019.1566756

\section{PUBLISHER}

Taylor \& Francis @ Global Alliance of Marketing \& Management Associations (GAMMA)

\section{VERSION}

AM (Accepted Manuscript)

\section{PUBLISHER STATEMENT}

This is an Accepted Manuscript of an article published by Taylor \& Francis in Journal of Global Sport Management on 5 February 2019, available online: http://www.tandfonline.com/10.1080/24704067.2019.1566756.

\section{LICENCE}

CC BY-NC-ND 4.0

\section{REPOSITORY RECORD}

Chen, Shushu, Holger Preuss, Xiaoqian Hu, James Andrew Kenyon, and Xiao Liang. 2019. "Sport Policy Development in China: Legacies of Beijing's 2008 Summer Olympic Games and 2022 Winter Olympic Games". Loughborough University. https://hdl.handle.net/2134/36057. 


\section{Journal of Global Sport Management

\section{Sport Policy Development in China: Legacies of Beijing's 2008 Summer Olympic Games and 2022 Winter Olympic Games}

\begin{tabular}{|c|l|}
\hline Journal: & Journal of Global Sport Management \\
\hline Manuscript ID & RGSM-2018-0041.R2 \\
\hline Keywuscript Type: & Original Empirical Paper \\
\hline Abstract: & $\begin{array}{l}\text { China, Beijing 2008 Summer Olympic Games, Beijing } 2022 \text { Winter } \\
\text { Olympic Games, sport policy, legacy }\end{array}$ \\
& $\begin{array}{l}\text { The aim of this article is to explore Olympic-led sport policy changes (as } \\
\text { part of Olympic legacy) for China triggered by the 2008 Summer } \\
\text { Olympics and the 2022 Winter Olympic Games. Although there has been } \\
\text { a burgeoning of research interest in analysing Olympictriggered changes } \\
\text { and legacies, with focus on various areas such as economic, } \\
\text { nocions the hosting of the policy. Drawing from policy document analysis, the paper } \\
\text { reveals that the two Olympic Games collectively helped to expand the } \\
\text { role and value of sport in China and to elevate the status of mass sport. } \\
\text { In terms of policy, China's two bidding experiences led to a streamlining } \\
\text { of policy making and legacy planning processes for sporting mega } \\
\text { events. The paper ends with a discussion of the implications associated } \\
\text { with strategic policy planning for future Olympics hosts. }\end{array}$ \\
\hline
\end{tabular}

\section{SCHOLARONE" Manuscripts}


*For the special issue: Olympic Games and Legacy

\section{Sport Policy Development in China: Legacies of Beijing's 2008 Summer Olympic Games and 2022 Winter Olympic Games}

\section{Author names and affiliations:}

1. Dr Shushu Chen University of Birmingham, School of Sport, Exercise and Rehabilitation Sciences, University of Birmingham, Edgbaston, Birmingham, B15 2TT, United Kingdom, s.chen.5@bham.ac.uk

2. Professor Holger Preuss Johannes Gutenberg University, Institute of Sport Science, the Johannes Gutenberg-University, Mainz, Germany preuss@uni-mainz.de

3. Dr Xiaoqian (Richard) $\mathrm{Hu}$ Tsinghua University, Division of Sports Science and Physical Education, Tsinghua University, Beijing, China, richard x_hu@mail.tsinghua.edu.cn

4. Dr Jamie Kenyon Loughborough University, School of Sport, Exercise and Health Sciences, Loughborough University, Loughborough, United Kingdom, J.A.Kenyon@lboro.ac.uk

5. Xiao Liang University of Birmingham

School of Sport, Exercise and Rehabilitation Sciences, University of Birmingham, Edgbaston, Birmingham, B15 2TT, United Kingdom, XXL497@student.bham.ac.uk

Corresponding author: Dr Shushu Chen, s.chen.5@bham.ac.uk, Tel: +44 (0) 1214158386 Fax: + 44 (0) 1214144121, School of Sport, Exercise and Rehabilitation Sciences, University of Birmingham, Edgbaston, Birmingham, B15 2TT

Acknowledgement: This research was supported by a grant from the National Social Science Fund of China (16ZDA226). 


\section{Abstract}

The aim of this article is to explore Olympic-led sport policy changes (as part of Olympic legacy) for China triggered by the 2008 Summer Olympics and the 2022 Winter Olympic Games. Although there has been a burgeoning of research interest in analysing Olympic-triggered changes and legacies, with focus on various areas such as economic, sociocultural, and environmental issues, little is known about the changes that the hosting of the Olympics Games stimulates in a host nation's sport policy. Drawing from policy document analysis, the paper reveals that the two Olympic Games collectively helped to expand the role and value of sport in China and to elevate the status of mass sport. In terms of policy, China's two bidding experiences led to a streamlining of policy making and legacy planning processes for sporting mega events. The paper ends with a discussion of the implications associated with strategic policy planning for future Olympics hosts.

Keywords: China, Beijing 2008 Summer Olympic Games, Beijing 2022 Winter Olympic Games, sport policy, legacy 


\section{Introduction}

Since the term legacy first appeared in the Melbourne 1956 candidacy for the XVI Olympiad (Leopkey, 2009), debates on Olympic legacy analysis initially looked at how to define legacy, then moved on to how to measure legacy and, more recently, to how legacy is planned and delivered. The last decade has seen burgeoning research interest in legacy and impact analysis for the Olympic Games, encompassing areas mainly addressing economic impacts (Baade \& Matheson, 2002; Blake, 2005; Kasimati \& Dawson, 2009; Preuss, 2004), sociocultural impacts (Truno, 1995), environmental impacts (May, 1995; Zhou et al., 2010), reputational legacy (Berkowitz, Gjermano, Gomez, \& Schafer, 2007; Gold \& Gold, 2008; Zhang \& Zhao, 2009), political legacy (Preuss \& Alfs, 2011; Tomlinson \& Young, 2006), and infrastructural legacy (including both sporting and non-sporting legacy, see for example, Cashman, 2006; Hiller, 2006). However, impacts are often very short term and legacy, which derives from changes initiated from the staging of the Olympic Games are not so often investigated yet. Even worse is that legacy on domestic sport policy, ensuing from the hosting of the Olympic Games, have not yet received serious consideration.

Although hosting the Olympic Games inevitably brings about domestic policy changes (for sport policy in particular), long-term policy effects do not necessarily follow. Once the Olympic ends, fine-tuned policy (particularly sport policy) and related financial investments are often dialled back.

China has been 'obsessed' with the Olympic Games for more than a century (Xu, 2008), and as an Olympic host county, China presents a somewhat unusual case: Having hosted the 2008 Summer Olympics, the 2014 Youth Olympics and as hosts of the 2022 Winter Olympics, China will become the first country to host all versions of the Olympic Games within a 15 -year period. Beijing will therefore become a 'Double Olympics City' through its involvement with both the 2008 Summer Games and the 2022 Winter Games. 
This relative brevity of the time period in question creates appropriate conditions for one wave after another of Olympic impetus for policy change. We may thereby examine changes in policy patterns occurring between the two Olympic Games events, and it is against this background that our research unfolds. Drawing from Preuss' $(2015,2018)$ framework which is now also used by the International Olympic Committee (IOC) for identifying the legacies of a mega sporting event, this study aims to explore Olympic-led sport policy changes, as part of the Olympic legacy, in the case of China, using a document analysis approach.

\section{Olympic Legacies}

Hosting the Olympics has been seen as a catalyst for bringing about changes in host cities and countries. As a result, investigating Olympic legacies has been an ongoing area of concern within the field of sporting mega events over the last two decades (Agha, Fairley, \& Gibson, 2012; Dong \& Mangan, 2008; Girginov \& Hills, 2008; Gratton \& Preuss, 2008; Minnaert, 2012). More recently, the importance of the legacy assessment has been accentuated by the IOC following their call, as part of Agenda 2020 (IOC, 2014), for embedding sustainable and positive legacy in the organising of the Olympic Games.

Discussions surrounding the Olympic Games have shifted over time from a primary focus on the benefits and costs (in economic terms) for the host city and nation to the impacts created by the Olympics (in more general economic and social terms) and the legacies generated from hosting it (covering a wide range of the Olympics' outcomes). Although various definitions of legacy are available in the literature (Cashman, 2002; Chappelet, 2002; Getz, 1991), in this study, we follow Preuss' (2007) definition of legacy as it incorporates different dimensions and characteristic that are applicable to the topic of policy. Legacy can be referred to as follows:

Irrespective of the time of production and space, legacy is all planned and unplanned, positive and negative, tangible and intangible structures created 
for and by a sport event that remain longer than the event itself (Preuss, 2007, p.211).

Legacy, therefore, combines both the planned and the unplanned, the positive (e.g., economic boosts, urban and environmental transformation) and the negative (e.g., ineffective use of facilities, high opportunity costs, increases of property rental, loss of housing where Olympic facilities are built), and covers both the tangible effects (e.g., new sport structures and traffic infrastructure) and the intangible effects (e.g., knowledge of organising mega events, building business and political networks, 'feel good' factor, cultural ideas) at play before, during, and after the Games.

A large, growing body of literature has investigated Olympic legacies. This has, traditionally, primarily focused on economic and tourism effects (Baade, Baumann, \& Matheson, 2008; Brunet, 1995; Duran, 2002; Madden \& Crowe, 1998; Weed, 2008) and more recently on social, political, and destination image changes (Kenyon \& Bodet, 2018; Koutrou \& Pappous, 2016; Nichols \& Ralston, 2011; Preuss \& Alfs, 2011). Several comprehensive reviews of the literature on the topic of Olympic legacy are available for further consultation (Chen, 2013; Mangan \& Dyreson, 2013; Thomson, Schlenker, \& Schulenkorf, 2013). Collectively, these reviews outline the critical role of the Olympics for stimulating changes in multiple dimensions. However, overall, it is found that, in most publication, legacy is not analysed and empirical studies are limited to collecting subjective (expert) opinions which can be verified by the two recently published literature reviews from Scheu and Preuss (2017) and Koenigstorfer, Bocarro, Edwards, Jones, and Preuss (2017). Looking more closely at the Beijing 2008 Games, a number of studies published both in English and in Chinese have investigated Olympic legacies and impacts (Kapareliotis, Panopoulos, \& Panigyrakis, 2010; Kong \& Li, 2005; Ren, Wang, \& Niu, 2006; Zhou \& Ap, 2009; Zhou, Xin, \& Xiong, 2006). Specifically, in economic terms, for example, it was estimated that hosting the 2008 Olympic Games generated an extra 240 billion RMB in 
Beijing's GDP and increased employment by 3.5 million (Yang, 2005). By adopting the urban economic growth model and by using the panel data of Beijing, Jinan, and Guangzhou from 1978 to 2009, Sun, Liu and Mi (2013) calculated mega sporting events' impact on urban economic development, concluding that hosting the Olympics can speed up the pace of industrial restructuring and stimulate the development of regional social economy, bringing a $1.5 \%$ increase of economic growth to the host region. In Preuss and Alfs' (2011) study, they investigated how China used the Olympic Games to signal to, amongst others, potential business partners and investors and to change the perception and image of China.

In sociocultural terms, more than $92 \%$ of the national television population saw part of the 2008 Olympic Games (Liu, Yao, \& Lan, 2009). The event's positive, albeit short-term, impacts on enhancing the quality of life among the host residents - for example in terms of happiness and satisfaction (Gu, 2011; Wang, 2012) and of living standards (Chu, 2011) were noted. In a quantitative research with 1,165 Beijing residents, Zhou and Ap (2009) revealed that $96 \%$ of respondents supported the 2008 Olympic Games; and those residents perceived the Games' impacts most positively in terms of the social-psychological, urban development, and economic development benefits. Furthermore, several scholars have devoted their attention to examining political impacts of the Games, suggesting that hosting the Olympics was linked with improving China's international reputation and prestige (Dong, 2012) and that, by hosting the Games, China sought to advance its international influence and appeal via the means of soft power (Giulianotti, 2015). In summary, although the hosting of the 2008 Olympics has spawned Olympic-related research on various topics, there have been relatively few studies examining Olympic-led policy changes in the context of sport. 


\section{China's Sport Policy Development Prior to the Winning of the Beijing 2008 Bid}

\section{A Brief Overview of Sport Policy Development in China}

In general, sport has been considered as a relatively important area in China (Hong \& Lu, 2011). Since the People's Republic of China was established in October 1949, sport emerged as a recognised responsibility of government. During this period, the general well-being of the nation was poor; to some extent, it was considered that low levels of physical strength and health had started affecting national economic development (Xiao, 2009). The government of that time also understood that a nation's military strength was dependent on the 'quality' of the people involved. It was in this context that sport policies were formed which would enhance people's physiques, and popularise and regulate sports (Feng, 2008). The first official appearance of sport-related policy was in a constitutional document (Xia \& Tian, 2010), titled 'The Common Programme of the Chinese People's Political Consultative Conference' (Chinese Political Consultative Conference, 1949): Rule number 48 of this constitutional document aimed 'to promote a whole nation taking part in sports and exercises'.

From the late 1950s to the 1970s, sport-related development was disrupted under the background of the Great Leap Forward and the Cultural Revolution movements (Wu, 1999). The State Physical Culture and Sports Commission (SPCSC) formalised the 'Ten-Year Guideline for Sports Development' that aimed to 'vigorously develop mass sport' and to 'develop elite sport' simultaneously in order to reach world levels within a decade (SCPSC, 1958). In the aftermath of the Cultural Revolution in 1976, the focus of sport policy then moved to developing elite sport, in guaranteeing popularisation of mass sport (Wu, 1999). The subsequently established system of 'juguo tizhi' (the whole country support for elite sport system) and the publication of the first 'Olympic Glory Plan' (Sports Ministry of China, 
1995) marked the beginning of a forty-year era dominated by elite sport in China (Xiao, 2009).

One of the key reasons behind the adoption of this elite sport focus was that the overall investment in sport-related business was insufficient at the time; given the limited resources available, sport would be better off if most of the respective resources were directed into achieving breakthroughs in one area (i.e., elite sport) ( $\mathrm{Wu}, 1999)$. Thus, ever since, China's sports development has pivoted on the principle of prioritising elite sport, then leading subsequent general development (Wu, 1999). This prioritising of elite sport over mass sport was also due to the former's (more specifically, achieving Olympic success) perceived importance as a powerful vehicle for diplomacy (Xiao, 2009) and achieving soft power (Chen, J. et al., 2015).

To prioritise elite sport, the Chinese government used coercive power in relation to policy support and funding, which inevitably downgraded the significance of mass sport. A pro-elite sport national mood was gradually shaped, evidenced in the Chinese general public's passion for and pride in elite sport success, intolerance of elite sport failures, and relative neglect of mass sport - especially in the 1980s and 1990s (Zheng, et al., 2018). This national mood in the political stream was largely supportive of the government's elite-sportfavouring policy (Zheng, et al., 2018), and was further encouraged following the nation's first Olympic gold medal at the 1984 Los Angeles Olympic Games and, in the early 1980s, securing such as the Chinese Women's Volleyball Team, who won five consecutive world titles between 1981 and 1986 .

From 1995 to the early 2000s, although China enjoyed victories achieved in the arena of elite sport (and Olympic medal successes in particular), fresh concerns about citizens' health (in particular, in children and young people) increased attention around the issue of developing mass participation (Chen, X. \& Chen, S., 2016). Subsequently, the principle of 
'co-ordinately developing mass sport and elite sport' was put forward (Cui, 2004). This policy shift took place against the background of significant economic success which subsequently helped to considerably lift living standards in China (Xiao, 2009). The financial and resource pressure for sport development was eased, and the demands for sports and health requirements were strengthened. The increased public demand for physical health and mental wellbeing reflected shifts in the national mood. The most noteworthy change was the publication of the National Fitness Programme in 1995, which suggested that China finally accommodate mass sport. The National Fitness Programme aimed to promote exercise for the benefit of economic development and aimed to improve national health and the fitness levels of the population (The State Council of the People's Republic of China, 1995). However, despite the change of policy goals, there was a lack of detailed explanation and guidance on how to implement the changes, reflected by the government's rhetorical support towards development of mass sport.

\section{The Significance of the Olympics to China}

Sports mega events, particularly the Olympics, have multiple functions that transcend sport. This is particularly so for China, which perceives such events as arenas where power, (social, cultural, and sports) activities, and political order are exercised by and exchanged between different nations (Hu \& Henry, 2016). The Olympics seem to offer a possible solution for China to pursue international recognition and to realise its broader plans for national renewal (Xu, 2008). As explained by Xu (2008), Chinese exuberance at hosting the 2008 Olympics happened against a background of Chinese people being 'obsessed with their country's international status and their own identity as Chinese' (p. 6). As further suggested by several scholars, the hosting of 2008 Olympic Games was, in fact, a political effort for exercising public diplomacy and enhancing soft power for China (Pi, 2015; Wan, 2009). Indeed, Nye's (1990) notion of soft power (generally referring to international actors to advance foreign 
policy by engaging foreign publics) has manifested in the case that China bid for and successfully hosted the 2008 Olympics Games (Manzenreiter, 2010; Pang, 2008).

For more than a century, hosting an Olympic Games was a national dream (Xinhuanet, 2008). Although Beijing failed in its bid for hosting the 2000 edition of the Olympics Games, this did not stop China's overall Olympic ambitions. In support of China hosting the Olympic Games in the future, the then Chairman of CCP, Deng Xiaoping, suggested that the unsuccessful bid did not matter; China needed to learn its lesson and try again (Party Literature Research Center of the CPC Central Committee, 2004). In 1999, Chinese officials submitted their application to host the 2008 Olympics, in which it indicated that:

For China, to bid for the Olympic Games again was not only a great cause dedicated to promoting the Olympic spirit and enhancing cultural exchanges between the East and the West, but also an important opportunity to demonstrate China's achievements in reform and opening up and to accelerate the country's economic and social development (BOCOG, 2001, p. 13).

The above discourse, and the subsequent bids for the hosting of the 2014 Youth Olympics Games and the 2022 Winter Olympics Games, indicated China’s long-time passion for the event. From the time of Deng Xiaoping (1978 to 1989), followed by Jiang Zeming (1989 to 2002), then Hu Jintao (2002 to 2012), and finally Xi Jinping (2012 to present), the state's quest for the staging of the Olympics has been consistent. Jiang's view was that 'the Olympic Games is the largest sports event in the world' and he said, 'the Chinese government and people are fully supportive' of Beijing's bid for the 2008 Olympics (People.com.cn., 2000); Hu noted that 'in order to achieve the Chinese nation's century-long hope of hosting the Olympic Games, the Chinese people have pursued and struggled for a full hundred years and have sacrificed the hard work of several generations' worth of perseverance.' (cited ChinaNews, 2008); more recently, the 2022 Winter Olympic bid was backed by Xi in his 
speech during the 2022 bid presentation (Beijing 2022 Olympic Winter Games Bid Committee, 2015).

\section{Theoretical Framework}

While there has been some previous work in the literature that proposed theoretical frameworks for understanding sporting-mega-event legacies - for example, Kassens-Noor et al.’s (2015) mega-event legacy framework, Li and McCabe's (2012) framework for measuring the socio-economic legacies of mega-events, and Gratton and Preuss' (2008) work - these frameworks were not adopted for this study because, one, the focus of some of the above-mentioned frameworks often lies in measuring legacies, rather than identifying them. In the context of this research, policy legacy is potentially identifiable but difficult to quantify. Second, it is considered that some frameworks (e.g., Kassens-Noor et al., 2015) merely categorise or group mega-event legacies at or on different scales, offering little in the way of detailed analysis of the legacy identification process.

In comparison, Preuss' $(2015,2018)$ framework of a mega sporting event legacy identification proposes an approach for identifying event-related changes systematically, on which this paper draws for identifying Olympic-led policy changes (as part of the Olympic legacy). Having recognised the difficulty in determining mega sporting events' impacts, Preuss (2015) has called for event-related changes to be distinguished from independently occurring changes. He also suggested the notion of 'value in context' (Preuss, 2015, p.654), meaning that a legacy can be positive for some people but negative for others. Being aware that different stakeholders perceive emerged changes differently could help the determination of the value of any legacy. In addition, the framework takes consideration of a long-time period stretching from as early on as the decision to bid for an event until years after the 
event's staging. The framework also suggests being cautious about the duration of the legacies, as positive legacies might turn into negative legacies or vice versa.

Specifically, in relation to the identification of event-related development, Preuss (2015) classifies four types of changes triggered by hosting a mega event: Field A includes changes that occurred not because of the event. Field B includes developments planned in advance that would happen in the absence of a mega event but for which the event is likely to accelerate effects or processes. Field $\mathrm{C}$ refers to those changes required by the event but not a part of the long-term city development plan. Field D, termed a 're-used legacy' (Preuss, 2015, p.651), represents those developments needed for the event and constructed for different uses (requiring little or no extra costs for adaptation). Thus, the separation of the four fields helps to distinguish: (a) whether a change occurring can generate positive or negative legacy and (b) whether the developments constitute event-led changes. The principles of the framework, therefore, seem to offer some important insights into identifying Olympic-led policy changes, and to provide a holistic approach to organising discussion in this research.

\section{Research Method}

\section{Study Design}

This paper considered hosting the Olympics to be a critical event generally prompting accelerated changes in many respects for the host city and country, potentially leading to the emergence and development of legacy. In an attempt to explore policy development and changes occurring as a result of hosting the Olympics, this exploratory study focuses on the case of China - as a country that has already hosted the Beijing 2008 Summer Olympics and is about to host the Beijing 2022 Winter Olympics. The reasoning for omitting the Nanjing 2014 Youth Olympics the analysis is threefold. First, in terms of the scale and international influence, the Youth Olympics Games is a relatively small and unknown event due to how 
recently it became part of the Olympic family (the first Youth Olympics was held in Singapore in 2010), compared to the Summer and Winter Olympic Games. Second, the host city of the 2014 Youth Olympics (Nanjing) was different to that of the 2008 Summer and 2022 Winter Olympics (Beijing). Finally, in recognition of contextual features, there is a consistency of culture, of organisational structure, of strategies, and of plans at a city level when considering the 2008 Summer Games and 2022 Winter Olympics as catalysts that have brought policy changes for Beijing.

To apply Preuss' framework $(2015,2018)$ in tracing policy development, from the time of the successful bid to host the 2008 Olympics in 2001 up until 2016, this study aims to explore the characteristics and patterns of change for sport policy statements and interventions triggered by the Beijing 2008 Games and the Beijing 2022 Games. Specifically, the study seeks to identify what the Olympics-related policy changes are and when and how those changes occurred by conducting a qualitative document analysis. The application of qualitative document analysis has been widely used in social research (Bryman, 2008), and more specifically in the field of sport policy studies (Daugbjerg, et al., 2009; Goodwin \& Grix, 2011; Hayhurst, 2009). Considered as a 'staple in qualitative research' (Bowen, 2009, p.27), documents are useful in understanding the meanings that make up social reality (May, 2001) and in identifying phenomena among which patterns of relationships are established (Blaikie, 2010). This approach is particularly applicable to qualitative case studies where an intensive study focusing on producing rich descriptions of a single phenomenon is carried out (State, 1995; Yin, 2014). Thus, considering the nature of policy analysis and the lengthy period for legacy identification, as discussed above, the purpose of applying document analysis for this study is to seek convergence and corroboration, and to review the salience of the published sport-related policy and documentation, including government documents and official publications of sports governing bodies in China - for example, national sport 
strategies, policy-related documentary materials, operation and action plans, and other reports (see Appendix).

\section{Data Collection}

The policy document searching process incorporated two stages: For the first, a list of titles of sport-policy-related documents published between 2001 and 2016 was organised, drawing from a series of 'Chinese Sport Policy Compilations' issued by the General Administration of Sport of China ${ }^{[1]}$ (the GAS). These compilations are the most comprehensive and authoritative collections that summarise annual sport policy documents published by the State Council $^{[2]} \square$ government departments in charge of sport, national and local sports governing bodies, local party committees, congresses, people's governments, and sports administrative departments along with other relevant departments. From there, all national and Beijing sport policies were singled out for their full documents to be downloaded.

The second stage of the policy document searching process involved a manual searching process to screen all sport-related policies at both the website (under the section of 'policy') of the State Council and the GAS website (under the 'Information Release' section). As we were interested in identifying all sport-related policy changes triggered by the Olympics, we incorporated a broad range of terms in search strings in an attempt to capture cross-sectional sport policy areas (e.g., sport industry, mass sport, and elite sport) that might be impacted by the staging of the Olympics. Thus the search strings used were expanded from the 'Olympics' (奥运) and 'mega events' (大型赛事) which are more specific terms in Chinese, to 'sport' (体育) in general, covering the period from 2001 to 2016. In addition, several policy documents published before 2001 were included in the reviewing process; these were perceived to be landmark documents published before the winning of the 2008 
Olympic bid that served as 'baseline data' for our identification of policy changes (see Appendix).

After the duplicates were deleted, there remained 115 policy and strategy documents identified in the initial search based on their relevance to the topic. From there, 35 policy

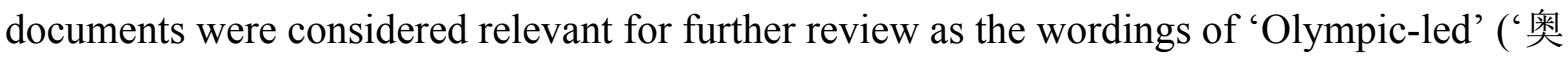
运’ ，带动下产生’ ), 'Olympic-inspired’ (“奥运’ ， ‘契机’ ), ‘Olympic-triggered’ ( “奥运’，“引发’ ), or ‘Olympic-accelerated’ (“奥运’ ，“激励” ) were evidenced.

\section{Data Analysis}

Qualitative content analysis (Altheide, 1996) was adopted to analyse the 35 policy documents included at the final stage. This technique is drawn upon in order to understand how different discourses structure the activities of actors and how activities are produced, how they function, and how they are changed (Howarth, 1995). We were interested in identifying not only what the documents contain, but also what they do not say, as per May's (1997, p. 164) argument that 'documents do not simply reflect, but also construct social reality and versions of events'; they are viewed as media through which social and political power is expressed.

Specifically, following Bowen's (2009) guidance, the analysis procedure consisted of three steps: skimming (superficial examination), reading (thorough examination), and interpretation. An initial stage of document review was conducted, aiming to identify definitions, meanings, processes, relevant passages of text, and types of policy changes. The data were then coded according to their relevance to the research aims and theoretical framework/underpinning in establishing initial themes (Ryan \& Bernard, 2003), including policy focus, missions and targets, operating contexts, Olympics-related elements, organisational structure, and management approaches. Data were then reread and organised into what/how/when/who folders, and this finally led to the identification of the three themes: 
1) the values and roles of sport; 2) mass sport development; and 3) sporting mega events policy planning (see Table 1).

[Insert Table 1 here]

\section{Findings}

The following sections present an examination of the emergent themes identified from the document analysis.

\section{Expanding the Values and Roles of Sport}

Although the importance of sport in China's public policy has long been recognised, it was treated as a standalone single sector that had interacted minimally with other sectors (e.g., tourism, culture) prior to the 2000s. As previously mentioned, the key principles for sport development pivoted on popularising mass sport and enhancing elite sport performance (Xiao, 2009) between the 1950s and early 1970s, and on prioritising elite sport, then on leading subsequent general development (Wu, 1999) during the later 1970s and early 2000s. The roles sport played in Chinese society were viewed as health-related (through developing mass sport) and as having political significance (through developing elite sport success) (Wu, 1999). There was little discussion in the reviewed sports strategic documents published before 2000 concerning the economic benefits of sport, sport industry, and how sport might contribute to China's overall economic and social development. Our evidence points to a singular lack of coalition planning across sectors and failure to recognise a wider range of values for sport.

However, the winning of the 2008 hosting rights in 2001 appeared to contribute to the rise in salience, at central government level, of sport. The significance of the decision to award the right of hosting the 2008 Summer Olympic Games to Beijing in 2001 is beyond debate (GAS, 2008, 2009), and a broader consensus is that this was not only a milestone in 
sporting terms, but it was also a key event for the whole nation and had profound political, economic, and cultural impact (GAS, 2008; Yang, 2012). Such linkage between hosting the Olympics and the enhancement of national and host city's image was also recognised in other Olympics Games, e.g. the Seoul 1988 Games (Kim et al., 1989).

More importantly, Beijing 2008 provided an opportunity to redefine and expand the role of sport and triggered further strengthening and improving of sports work, particularly sport's role in generating social and economic benefits. One year after winning the 2008 hosting rights, the document titled 'The Communist Party of China Central Committee and the State Council's Opinions on Further Strengthening and Improving Sports Work in the New Era' (hereafter referred to as the No. 8 document) published by the State Council (2000) explicitly called for full recognition of the important role played by sports in economic and social development. This document came out immediately after the 2008 Olympic bid was won, despite another strategic document, 'Outline of the Sports Reform and Development in 2001-2010' (The State Council, 2000), having already released several months prior to the winning of the bid. Such frequent issuing of sport policies at the top level of government had rarely before been seen; this reflected how much attention the state was paying to sport and also outlined an ambition in achieving a much broader agenda through sport. These eventrelated changes are worth of distinguishing from changes occurring independently (Preuss, 2015).

For the first time, sport was linked with 'advancing human civilization' (The State Council, 2002b, the No. 8 document, Section 1), 'the means to promote friendship and unity' (The State Council, 2002b, the No. 8 document, Section 1), and 'the need to establish a socialist market economic system' (The State Council, 2002b, the No. 8 document, Section 1). The No. 8 document further explained the rationales behind bidding for the 2008 Olympics: 
Hosting the 2008 Olympics presents a rare opportunity to promote China's economic and social development and to further enhance China's status and prestige in the international sports arena. The Olympics provides a big stage for improving the level of China's elite sport and organizing international large-scale events; it is a 'university' for studying international sports affairs and mastering modern sports operation methods; it can also act as a 'melting pot' to temper sports teams' thinking and professional qualities. (Section 4.13)

Therefore, the value of the Olympics for promoting China's economic and social development was officially recognised by the government. Following this, the GAS reinforced the comprehensive role of the 2008 Olympics in 'influencing and leading economic development, social development, political stability, [and] cultural prosperity' in the strategic document of the $11^{\text {th }}$ Five-Year Plan ${ }^{[3]}$ for Sports Development (GAS, 2006a, Section 2.6). Hosting the 2008 Olympics was particularly perceived as a 'golden opportunity for the development and progress of China's sports' (GAS, 2006a, the 11th Five-Year Plan for Sports Development document, Section 1.3), and it became more apparent that 'the relationship between sport and economy gets closer and closer, penetrating, depending on, and promoting each other' (GAS, 2006a, the $11^{\text {th }}$ Five-Year Plan for Sports Development document, Section 1.3).

After the successful staging of the 2008 Olympic Games, the policy discourse changed from 'gaining full recognition of the important role of sports in economic and social development' outlined in the $11^{\text {th }}$ Five-Year Plan (GAS, 2006a), to 'further maximising the unique role of sports in promoting economic construction, political construction, cultural construction, social construction, ecological civilization construction, and diplomacy' (GAS, 2011a, the 12th Five-Year Plan, Section 2.6).

Despite there being a gradual increase in recognition of the significant roles sport played in China's social and economic development, relevant policy discourses were largely abstract and rhetorical, and they lacked clarity and specific policy mechanisms until after 
2015 when the 2022 Winter Olympics bid was secured. This time, the award of the 2022 Olympics hosting rights prompted the use of sport (or, more specifically, the Olympics Games) for achieving economic and social development. It was made more explicit that the Winter Olympics could be organised in such a way as to coordinate with the National Strategy of Coordinated Development for the Beijing-Tianjin-Hebei Region ${ }^{[4]}$ (GAS, 2016a, the $13^{\text {th }}$ Five-Year Plan, Section 6.28), and the subsequent results are considered to be an important measure for the success of the policy's delivery. Therefore, in contrast with the previous vague and ambiguous content, the level of detail regarding policy tasks was made explicitly and quantifiable. It may well be the case that the winning the 2022 Winter Olympic hosting rights has finally provided an opportunity to capitalise on industrialisation of sport ambition, with sport being viewed as 'a symbolic cause of the great rejuvenation of the Chinese nation' (GAS, 2016a, the $13^{\text {th }}$ Five-Year Plan, Section 1.3).

\section{The Rise of Mass Sport Agenda}

There was evidence of changed discourse, in the reviewed policy documents, about how the 2022 Olympics acted as a catalyst to promote the development of mass sport. As discussed earlier, mass sport has long held a position within China's sport-related agenda and yet has taken a back seat for the past forty years. The idea of 'co-ordinately developing mass sport and elite sport' was touted in the National Fitness Programme (The State Council, Section 4.16) in 1995, after China achieved significant economic success, and the financial and resource pressure for sport development was eased and the demands for sports and health requirements were strengthened. However, in reality, political attention and state financial investment were for the most part still strategically placed on the development of elite sport during the preparation for the 2008 Olympic Games (Zheng, 2015).

The winning of the 2008 bid seemed to do less in changing sport policy direction: Elite sport still received high priority (Hu \& Henry, 2017); apart from the launch of the 


\section{'Promoting and National Fitness Programme Together with the Olympic Games' campaign}

(GAS, 2006a) and some sporadically issued policy statements relating to the agenda of developing mass sport, the ideal of mass participation had received little more than lip service.

Nevertheless, the successful hosting of the Beijing 2008 Olympic Games acted as a turning point for China's overall sport development, as evidenced by the introduction of a new political mission that was assigned to Chinese sport after the 2008 Olympics (Bao, 2010; Liu, 2009). This significant policy change triggered by the hosting of the 2008 Olympics endorsed the principle of transforming from a Major Sports Country to a World Sports Power proposed by the then President, Hu Jintao, at the commendation ceremony for the Beijing Olympic Games and Paralympic Games in 2008. Put simply, this principle marked the beginning of a comprehensive development in Chinese sport, which aimed to deemphasise elite sport and sought to divert attention and resources to other areas, e.g., mass sport and sport industry (Research Group of the Studies on Theory and Practice of Stepping from a Major Sports Nation to a Strong Sporting Nation, 2010). As explained by Bao (an internal researcher of the GAS, 2010, p. 6) 'a Sport Power ...is people oriented'. Thus, the proposed principle can be viewed as a long-awaited direct response to the issue of unbalanced development between the strands of elite sport and mass sport.

However, although the rhetoric of reform was in evidence, as Hogwood and Gunn (1984) have previously warned us, the identification of an issue does not automatically imply that instant action or any action at all by governments is called for. Indeed, for more than five years after the introduction of the Sports Power principle, there were virtually no concrete plans being put into place to drive the development of mass sport until the idea of bidding for the 2022 Winter Olympics was born in 2013 and 2014. Specifically, in preparation for the bid to host the 2022 Winter Olympics, President Xi proposed the idea of 'using the 2022 Games 
to get a population of 300 million in China to play winter sports' (The Chinese Olympic Committee, 2017). On this occasion, President Xi's support secured the policy status and government support for mass sport within the CCP government. This ambition for the 2022 Winter Olympics was relatively detailed and significant, compared to the policy goal of 'using the opportunity of the 2008 Olympics to carry out mass sports activities' in the 2008 Olympian period (GAS, 2006a, the 11th Five-year Plan, Section 2.4); linking an Olympic event with developing mass sport had not been explicitly addressed when the 2008 Olympics were hosted.

Following President Xi's remarks, a few months later, a strategic document titled 'Opinions of the State Council on Accelerating the Development of Sport Industry and Promoting Sports Consumption' (hereafter, the No. 46 document, The State Council, 2014), was published. This represented a watershed in the policy status of mass participation in China: For the first time, the State Council explicitly recognised the importance of mass sport, suggesting that the status of mass sport should 'be upgraded to a state priority'. It signalled a clear government desire to develop mass sport, urged by growing concern about the deterioration of children's physical fitness and about a steadily increasing percentage of adults becoming overweight. Specifically, this strategic document indicates that

\begin{abstract}
The development of sport and sport industry must take as its fundamental goals the strengthening of the people's physiques and the improvement of the physical quality and health of the Chinese nation; in order to meet the diverse sports needs of the people, we should take innovative approaches to protect and improve people's lives, to promote democracy, and to enhance national cohesion and cultural competitiveness. (The State Council, 2014, p.1)
\end{abstract}

Thus, hosting the 2022 Olympics provides an opportunity to capitalise on the proposed Sports Power principle in general, and more specifically for the government to invest in mass sport participation and to reinforce administration, which has further elevated the profile of mass sport in China. Several concrete measures were set out explicitly in this 
document, including ensuring that per capita playing area would reach two square meters, having at least 0.5 billion people taking part regularly in sport and physical activities by 2025, establishing '15 minutes Fitness Circle' ( $\square \square \square$ 钟 $\square \square$ ), et cetera. All these clear and quantified, rather than abstract and rhetorical, policy objectives are manifestations of Olympic-led policy changes on aspects of implementability, correctness, and specification (Pettigrew, Ferlie \& McKee, 1992). Since the publication of the No.46 document, the tilted policy attention seemed to be restored. The improved profile of mass sport is also evidenced in a better-balanced ratio of policy sections devoted to elite sport versus mass sport. As can be seen from the Table 2, the gap between mass sport and elite sport has closed, in terms of the number of sections being allocated to each of the two strands in the national policy documents, with numbers of mass-sport-related policy objectives surpassing those of elite sport for the first time in the most recent Five-Year Plans.

[Insert Table 2 here]

Regarding changes in organisational structure (Preuss, 2015), right after winning the 2008 bid, it was mentioned in the No.8 document that

\begin{abstract}
Using the favourable opportunity of preparing for the 2008 Olympic Games, we will give full credit to the roles played by the GAS, the All-China Sports Federation, and the Chinese Olympic Committee. According to our country's national conditions, we must learn from the successful experiences of foreign countries and gradually streamline the relations between sports organisations at all levels, divide labour and cooperation, and form an organisational structure that is conducive to the development of sports in the new era and a mode of operation that suits the requirements of the socialist market economy. (The State Council, 2002b, Section 5.19)
\end{abstract}

As exemplified in the above statements, it was recognised that hosting the 2008 Olympics provided a 'favourable opportunity' for addressing mass sport's fragmented and 
disjointed system, on the premise of maintaining the centralised decision-making authority of the GAS, the All-China Sports Federation, and the Chinese Olympic Committee. In 'The Regulation on National Fitness' published by the State Council (2009), two key policy implementation measures were incorporated, requiring that 'the national fitness programme should be incorporated into the social and economic development plans of all counties, at the county level and upwards' (The Regulation on National Fitness, Item 2) and that 'the funds required for national fitness should be included in the local government financial budget for all counties, at the county level and upwards' (The Regulation on National Fitness, Item 26). Such clarity of role identification and specificity of implementation for all of the organisational levels involved was intended to fully mobilise the National Fitness Programme and to overcome remaining bureaucratic obstacles at various levels.

Furthermore, the establishment of the Youth Sport Development within the GAS, and the launch of the China Association of Social Sports Instructors mechanism in 2010 were significant structural changes that aimed to support the delivery of the aforementioned policy changes.

In addition, the rise of mass sport's status was further reflected by the amended rationing of the annual sports lottery fund. Since the introduction of the sports lottery in 1994, the proportions of funding allocation to mass sport and elite sport were set at $60 \%$ and $40 \%$ respectively. This continued for almost twenty years until recently, following the publication of the 'Centralized Lottery Public Welfare Fund Supports Sports Special Fund Management Measures' in 2013 (GAS, 2013), this ratio changed to 70\% (mass sport) and 30\% (elite sport). As Table 3 further indicates, in comparison with the $46.3 \%$ of the sports lottery public welfare funds being spent on mass sport in 1996, the proportion of the spending was in reality raised to $88.6 \%$ in 2014 ; and in general, there has been a gradual increase in the proportion of 
sport lottery public welfare funds being spent on mass sport (Yang, 2015), which serves as another indicator for the change of policy direction.

\section{[Insert Table 3 here]}

\section{Sporting Mega Events Policy Planning}

As a part of the 'event structures' (Preuss, 2015, p.651) and finally implemented as policy and governance (Preuss, 2018), policy, particularly in terms of policy planning and learning, was generated by the successful bidding and hosting of the 2008 Olympic Games. Two successful Olympics-bidding experiences helped to streamline the policy planning process whereby mega sporting events are strategically used to develop sport and sport-related businesses for the purpose of generating sustainable legacies. In the only general sport policy guideline (GAS, 2006a, the $11^{\text {th }}$ Five-Year Plan) published during the 2008 Olympic preparation period, 2008-Olympics-related plans were scattered over the 'elite sport' and 'mass sport' sections, and content was primarily impact focused, rather than being legacy focused. Relevant visions were largely short-term, simple, intangible, and lacking implementation mechanisms and measures (GAS, 2011a, the $12^{\text {th }}$ Five-Year Plan, Section 2.6).

Yet, the 2022 Olympics-related plan was singled out as a priority, outlined in a specific section in the $13^{\text {th }}$ Five-Year Plan (again, these were the only top level sport policy guidelines published during the 2022 Olympian period, GAS, 2016a, Section 6), the content of which intertwined not only with elite sport development and mass sport but also with sport industry and school sport. The 2022 Olympic section consisted of three sub-areas, including 'popularising ice and snow sports projects' (mass sport, youth sport, and sport industry related), 'improving the level of winter sport competition' (elite sport related), and 'actively 
organising and preparing for the 2022 Beijing Winter Olympics' (detailed legacy plans were outlined here).

In contrast with the $11^{\text {th }}$ Five-Year Plan, in which the 2008-Olympic-related strategy was vague and dealt with swiftly, the $13^{\text {th }}$ Five-Year Plan provided a more detailed account discussion and proposed a range of mechanisms for the 2022 Winter Olympics' preparation, such as the 'Winter Sports Promotion Plan', 'Promoting Ice and Snow Sports among Youth', and 'Snow Sports: Expanding its Development in the South; Promoting it in the West'.

Particularly, in relation to legacy planning, compared to the 2008 occasion on which the government only called for 'placing more emphasis on the 2008 Olympic legacy research and knowledge agreement' (GAS, 2011a, the12 ${ }^{\text {th }}$ Five-Year Plan, Section 2.6), but nothing else concrete, the 2022 Winter Olympic legacy plans proposed some significant changes: Most notable is the change of organisational structure evidenced by the establishment of a specific institution for Beijing 2022 legacy planning and coordination and a careful plan of use for the facility legacy of the 2008 Olympics.

In addition, the 2022 Winter Olympic legacy plan has for the first time been linked with a broader agenda - the National Strategy of Coordinated Development for the BeijingTianjin-Hebei Region (Central Financial and Economic Affairs Commission, 2015) mentioned earlier - by introducing the programme of 'the Beijing-Zhangjiakou Sport, Culture, and Tourism Belt' (Beijing 2022 Olympic Winter Games Bid Committee, 2014). This programme, as one of the key 2022 Olympic legacies, aims to boost the regional economic development and accelerate the implementation of the air quality improvement plans, and it is anticipated to contribute 20\% to Beijing's GDP by 2020 (Yi \& Wang, 2016).

Another planned legacy outlined in the bid document was the aforementioned ambition of 'using the 2022 Games to get a population of 300 million in China to play winter sports' (BOCOG, 2015, Official bid document of the Beijing-Zhangjiakou 2022 Winter 
Olympic Games, Volume1, Vision 1.1). To facilitate the delivery of the legacy plan, some detailed mechanisms were put forward to enhance the public acquaintance with and participation in winter sports at the national level (GAS, 2016b) and the city level (Beijing Municipal Government, 2016). For example, winter sports are in the process of being brought into the PE curricula for all primary and secondary schools in Beijing to ensure at least one hour per week of winter sport participation. Beijing is also set to establish 100 Winter Sports Featured Schools and 30 Youth Winter Sports Activity Centres by 2022, in order to expand the coverage of winter sports among youth.

\section{Discussion}

This study thus indicates that, in China's case, certain policy changes proved to be fruitless in the short term, and most policies were shaped over a long period to allow some actual activities to be adopted. This again demonstrates the protracted process of Olympic legacy planning and delivery (Gratton \& Preuss, 2008; Ritchie, 2000). While it is worth noting the existence of some contextual factors that have had discernible value as far as triggering change, e.g., the long prehistory of the call for reform (Hu \& Henry, 2017) and China's economic take-off in the 1990s (Yang, 2013), the catalysing impact of the two Olympics on accelerating sport policy development is apparent.

Most importantly, hosting two Olympics within a short period have brought policy promises under the spotlight, thereby avoiding policy relapses, to drive consecutive waves of policy change, which led to the emergence of policy legacy. This kind of legacy resonates with Smith and Fox's (2007) notion of 'event-led' (in contrast to 'event-themed') approach of legacy planning. In this regard, Brazil demonstrated a similar case where an event-led planning model for legacy development was evidenced, as indicated in Sánchez and Broudehous' (2013) research that the staging of the 2014 Football World Cup and the 2016 
Olympics played the key roles in driving the reconfiguration process of the urban landscape in Rio de Janeiro.

From Preuss' $(2015,2018)$ perspective, Olympic-led changes can be segmented into four fields (Field A-D) which can be helpful for identifying major policy change, resulting from the bidding for and hosting of the two Olympics, that are directly or indirectly associated with the two Olympic Games. The difficulty, however, lies in distinguishing Field B or Field C from Field A, for the purpose of identifying the 'net', rather than 'gross', legacy/impacts of sporting mega-events have been recognised acknowledge (Chen, Henry, \& Ko, 2013; Preuss, 2015; Weed, 2015).

In our case, there were short-term elite sport legacy goals (Chen, Zheng \& Dickson, 2017) identified from document analysis, e.g., increasing the number of Olympic gold medals won at the Olympics and maintaining the leading position in the gold medal table (GAS, 2011b), which were non-event-related developments that would have happened irrespective of winning the 2008 and 2022 Olympic hosting rights.

Regarding Field B legacies (referring to those changes that a city would have seen even without the Olympics happening there but that were accelerated as a result of hosting the Olympics), it was evidenced by our document review that, for example, the National strategy of Integrated and Coordinated Development of the Beijing-Tianjin-Hebei Region was proposed prior to the 2022 bid. As explained by a sports expert who participated in the preparation of the 2022 bid, the proposed Beijing-Zhangjiakou Sport, Culture, and Tourism Belt program was 'inspired' by this state initiate and subsequently become one of the performance measures (Yi \& Wang, 2016).

In an effort to identify Field $\mathrm{C}$ policy changes, representing changes needed only for the Olympics and not for a city's long-term development, we found that one of the bid legacies 'using the 2022 Games to get a population of 300 million in China to play winter 
sports' and its related policy plans were used to partly support the 2022 bid and subsequently to contribute to the 2022 Olympic staging legacy. While promoting sport participation has always been a priority at both national and city levels, encouraging winter sport participation was not advocated prior to the 2022 bid. China was not the first county who claimed to use sporting-mega-events to promote widespread sport and physical activity participation. A similar slogan - 'inspire a generation' (to do more physical and sport activities) (London 2012 Olympic Games Bid Committee, 2005) - was put forward by the British government in the case of the London 2012 Olympics. However, there is little empirical evidence to support such a claim (Mahtani, et al., 2013; Weed et al., 2015).

The transportation and venue facilities that were needed by the National Strategy of Coordinated Development for the Beijing-Tianjin-Hebei Region for the long term, but also satisfied the city's long-term needs for developing its winter sports industry (The National Speed Skating Oval, the Biathlon Centre and the Nordic Centre Ski Jumping Venue), are identified as part of the Field D legacy (the gaps of the city structure regarding future needs as a host city). Here, similar to the case of Japan where the facility legacies of one Olympics (i.e. Tokyo 1964) can be fully utilised when the next sporting mega-events (i.e. Tokyo 2020) are hosted (The Tokyo Organising Committee of the Olympic and Paralympic Games, 2015). For Beijing, those legacies - the legacies of the 2008 Olympic Games - might not be fully exploited if the 2022 Olympics were not coming (Yi \& Wang, 2016).

It was interesting to note the different roles that the 2008 Olympics and the 2022 Winter Olympics played in this policy-change process. Although winning the 2008 Summer Olympics hosting rights offered a policy window (Kingdon, 1984) for some potential sports reforms (e.g., addressing the imbalance between the development of elite sport and mass sport), there was 'great cry and little wool' during the seven-year period of preparation for the 2008 Olympic Games and the five-years post-Olympic period. As argued by Qiu (2016), 
there was a clear case of path dependence behind the resistance to priority change. The appearance of various sports-reform terminology in a number of policy documents during the 2008 Olympia, e.g., 'separating management from governing [and] starting a system reform' in the No.8 document (The State Council, 2002b, the No. 8 document, Section 5), 'establishing sports management mechanisms that adapt to the socialist market economy' in the $11^{\text {th }}$ Five-Year Plan (GAS, 2006a, the 11th Five-year Plan, Section, 6.36) $\square$ and 'deepening the reform of the sports science and technology management system' in the $12^{\text {th }}$ Five-Year Plan (GAS, 2011a, the 12th Five-year Plan, Section, 7.46), provide evidence of how the 2008 Olympics tried to drive sports reform. General sports development businesses were nevertheless reverted to their original 'path' of favouring elite sport. In terms of examining when a change occurs (Preuss, 2015), it was not until the successful bid of 2022 provided an opportunity to capitalise on such intentions, by incorporating specific and detailed mechanisms (e.g., the '300 million people play winter sports' initiative and the 'Beijing-Zhangjiakou Sport, Culture, and Tourism Belt'), that policy focus shifted towards increase support for the development of mass sport and sports industry. Therefore, in summary, the hosting of the 2008 Olympics helped to reveal some fundamental issues within the sporting system, and winning the 2022 Winter Olympics propelled follow-up policy planning and policy change. The 2022 Olympic Games also allows Beijing to exploit the legacies of the 2008 Olympic Games (in terms of infrastructure). This situation resonates, therefore, with Preuss' (2015, p.643) argument that 'a legacy will be activated only if environmental changes offer opportunities'.

\section{Conclusion}

This paper has aimed to identify policy changes and developments generated by China hosting the Olympic Summer and Winter Games. Our review of a range of policy documents 
and strategies has indicated that the staging of the Olympics provided opportunities for stimulating the development of Chinese sport, in terms of widening the roles it plays in Chinese society, moving beyond health benefits and political gains to the embracing of social and economic values.

There is also evidence to support the view that the two Olympic Games have elevated the status of mass sport in political agenda. The successful bidding for and staging of the 2008 Olympics helped to fulfil China's ambition of showcasing economic successes and achieving internationalism. During this process, some fundamental issues underlying the Chinese sport system were laid bare: unbalanced agenda development between elite sport and mass sport, lack of responsivity to the needs of the public, and lack of implementation and measurement for certain policy agendas (e.g., mass sport). Finally, the winning of the 2022 Olympic hosting rights provided an opportunity for China to take some action. Thus, the two Olympic Games effectively played different roles in triggering policy changes, with the 2008 Games exposing relevant issues and the 2022 Games capitalising on and activating the necessary changes subsequently planned.

Furthermore, in terms of policymaking for and planning of sporting mega events, our content analysis of a series of policy documents suggested that the two Olympic events, happening within a short period, have provided China with an opportunity to learn lessons regarding the importance of strategic clarity and of broadening the range of planned legacies - following the 2008 Olympics and to adapt accordingly for the 2022 Olympic Games. As a result, the process of legacy development through policy planning triggered by the 2022 bid has been clearer than was the case for Beijing 2008.

In reflection of the application of the event legacy identification framework (2015) in this study, while the framework was useful in terms of providing a holistic and systematic approach for identifying event legacies, its capability to embrace the examination of policy- 
change-related factors was somewhat limited. In this regard, Sabatier's (1988) model of policy change, focusing on competing advocacy coalitions within policy systems, might provide useful insights into data analysis and complement to Preuss' $(2015,2018)$ overarching framework.

The Olympic Games have been and will continue to be important phenomena at many levels (both personal and national) and in many respects (economically, socially, culturally, and politically) in China. While they can offer the public an experience of something unique and extraordinary, the Olympics have the ability to stimulate the development of a range of economic and social impacts. Our study adds to previous knowledge by highlighting the policy changes triggered by the hosting of the two Olympic Games. Thus, we add also to the IOC strategic legacy approach which was implemented in 2018 (IOC, 2017, p.30) and suggest a method to capture Olympic driven policy changes. The implication of our analysis of Olympic-led policy changes, generated by hosting the Olympics, is to encourage future host countries to develop an awareness of such policy-planning and development potential, as well as the tendency of a strategy to facilitate strategic planning that renders effective and purposive policy changes. However, this study was limited in some ways. First, the project employed only document analysis as a method for investigation, which renders the presentation of one-side of story i.e. the policy stakeholders' perspectives (Preuss, 2015). Future work is therefore encouraged to empirically examine government rhetoric and to identify the Olympics' legacy specifically associated with policy change and policy development evidenced in the processes of policy-making and policy implementation. Second, post-2022 Olympic policy legacy was not captured at the time of the research. Future research could continue to explore Chinese policy development trends after their engagement with the 2022 Olympics. 
Notes:

[1]. The GAS is the national governmental body responsible for all sport-related activities.

[2]. The State Council is viewed as the core regime of the People's Republic of China.

[3]. In accordance with the national Five-Year Plan for Social and Economic Development, the GAS publishes the Five-Year Plan for Sport Development, which outlines a series of sport development initiatives established for the entire country, and serves as the top set of sport policy guidelines.

[4]. This state strategy launched in 2015 aims at orderly relocating all non-essential functions from Beijing to neighbouring locations. The strategy entails adjusting the economic structure and rationalising space utilisation.

\section{References}

Agha, N., Fairley, S., \& Gibson, H. (2012). Considering legacy as a multi-dimensional construct: The legacy of the Olympic Games. Sport Management Review, 15(1), $125-$ 139. doi:http://dx.doi.org/10.1016/j.smr.2011.08.004

Altheide, D. (1996). Qualitative media analysis. London: Sage.

Baade, R., \& Matheson, V. (2002). Bidding for the Olympics: fool's gold? In C. Barros, M. Ibrahimo, \& S. Szymanski (Eds.), Transatlantic Sport: the Comparative Economics of North America and European Sports (pp. 127-151): Edward Elgar: London.

Baade, R. A., Baumann, R., \& Matheson, V. A. (2008). Slippery slope? Assessing the economic impact of the 2002 Winter Olympic Games in Salt Lake City, Utah. Région \& Développement, 31, 79-89.

Bao, M. (2010). The strategic research on major sporting nation to strong sporting nation. In R. g. o. t. s. o. t. a. p. o. s. f. a. m. s. n. t. a. s. s. nation (Ed.), Strategic research on strong sporting nation (1st ed., pp. 1-14). Beijing: Renmin Tiyu Chubanshe [People' Sport Press].

Beijing 2022 Olympic Winter Games Bid Committee. (2014). Candidature file for the 2022 Winter Olympic Games. Retrieved from Beijing:

Beijing 2022 Olympic Winter Games Bid Committee. (2015). A video given by the President, $X i$ Jinpin, during the bid presentation. Retrieved from Lausanne: https://www.youtube.com/watch?v=ztv8WFsRgQ

Beijing Municipal Government. (2016). Several Opinions on Accelerating the Development of Winter Sports [Jiakuai Bingxue Yundong Fazhan de Yijian]. Retrieved from Beijing:

Berkowitz, P., Gjermano, G., Gomez, L., \& Schafer, G. (2007). Brand China: using the 2008 Olympic Games to enhance China's image. Place Branding and Public Diplomacy, 3(2), 164-178.

Blaikie, N. (2010). Designing Social Research (2nd ed.). Cambridge: Polity Press.

Blake, A. (2005). The economic impact of the London 2012 Olympics. Retrieved from Nottingham: http://www.nottingham.ac.uk/ttri/discussion/2005 5.pdf

BOCOG. (2001). Official bid document of the Beijing 2008 Olympic Games Retrieved from Beijing: BOCOG.

Bowen, G. A. (2009). Document Analysis as a Qualitative Research Method. Qualitative Research Journal, 9(2), 27-40. doi:https://doi.org/10.3316/QRJ0902027

Brunet, F. (1995). [An Economic Impact Analysis of the Barcelona '92 Olympic Games: Resources, financing and impact].

Bryman, A. (2008). Social research methods (Third ed.). Oxford: Oxford University press. 
Cashman, R. (2002). What is "Olympic Legacy"? Paper presented at the The Legacy of the Olympic Games 1984-2000: International Symposium, Lausanne.

Cashman, R. (2006). The bitter-sweet awakening: The legacy of the Sydney 2000 Olympic Games. Petersham, N.S.W: Walla Walla Press in conjunction with the Australian Centre for Olympic Studies, University of Technology, Sydney.

Central Financial and Economic Affairs Commission. (2015). The Outline of the Plan for Coordinated Development for the Beijing-Tianjin-Hebei Region. Beijing: Central Financial and Economic Affairs Commission.

Chappelet, J. L. (2002). The legacy of the Olympic Winter Games: An overview. Paper presented at the The Legacy of the Olympic Games 1984-2000: International Symposium, Lausanne.

Chen, J., Zhou, C., Cai, C., Zhang, C., Liu, Y., Wen, B., . . Wang, J. (2015). Chinese sports culture: Soft power and its improvement. Beijing: Sciencp.

Chen, S. (2013). An evaluation of the sub-regional legacy/ impacts of the London 2012 Olympic Games in a non-hosting sub-region: a case study of Leicestershire. (Doctoral), Loughborough University Loughborough.

Chen, S., Henry, I., \& Ko, L.-M. (2013). Meta-evaluation, analytic logic models and the assessment of impacts of sport policies. In I. Henry \& L.-M. Ko (Eds.), Routledge handbook of sport policy (pp. 33-47). London: Routledge.

Chen, S., Zheng, J., \& Dickson, G. (2017). An organisational life cycle approach to exploring the elite sport legacy of Summer Olympic host nations: The cases of China (Beijing 2008) and Australia (Sydney 2000), International Journal of the History of Sport (In press).

Chen, X., \& Chen, S. (2016). Youth sport in China. In K. Green \& A. Smith (Eds.), Routledge handbook of youth sport (pp. 131-141). London: Routledge.

ChinaNews. (2008). A speech made by Hu Jintao at the Awards Ceremony for the Beijing 2008 Paralympics. Retrieved from Beijing: http://www.chinanews.com/gn/news/2008/09-29/1399096.shtml

Chinese Political Consultative Conference. (1949). The Common Programme of the Chinese People's Political Consultative Conference [Zhongguo Renmin Zhengzhi Xieshang Huiyi Gongtong Gangling]. Beijing: Author.

Chu, L. (2011). Large sports games after the social influence and evaluation content research. Journal of Sports and Science, 32(5), 82-85.

Cui, Y. (2004). A comparative study of the public sports policy in China and Japan. (PhD thesis), Shanghai University of Sports, Shanghai, China.

Daugbjerg, S. B., Kahlmeier, S., Racioppi, F., Martin-Diener, E., Martin, B., Oja, P., \& Bull, F. (2009). Promotion of Physical Activity in the European Region: Content Analysis of 27 National Policy Documents. Journal of Physical Activity and Health, 6(6), 805817. doi:10.1123/jpah.6.6.805

Dong, J. (2012). Main existing problems, reasons and countermeasures about China hosting sports mega events. Journal of Sports and Science, 33(3), 42-51.

Dong, J., \& Mangan, J. A. (2008). Beijing Olympics legacies: Certain intentions and certain and uncertain outcomes. The International Journal of the History of Sport, 25(14), 2019-2040. doi:10.1080/09523360802439031

Duran, P. (2002). The impact of the Olympic Games on tourism - Barcelona: the legacy of the Games 1992-2002. In M. d. M. i. M. Botella (Ed.), M. d. M. i. M. Botella Barcelona: Centre d'Estudis Olímpics UAB, Planeta, Ajuntament de.

Feng, H. (2008). The mass sports policy in the early time of New China Journal of Beijing Sport University, 31(7), 905-907.

GAS. (2006). The 11th Five-Year Plan for Sports Development [No.26]. Beijing: GAS. 
GAS. (2011a). The 12th Five-Year Plan for Sports Development. Beijing: General Administration of Sport of China.

GAS. (2011b). The Outline of the Strategic Olympic Glory Plan: 2011-2020.

GAS. (2013). Centralised lottery public welfare fund supports sports special fund management measures. Beijing: GAS.

GAS. (2016a). The 13th Five-Year Plan for Sports Development in China. Beijing: General Administration of Sport of China.

GAS. (2016b). The Plan for the Popularization of Mass Winter Sports 2016-2020 [Qunzhong Dongji Yundong Tuiguang Puji Jihua 2016-2020]. Retrieved from Beijing:

GAS (Ed.) (2008). Gaige kaifang sanshinian de zhongguo tiyu [Chinese sport in thirty years of Reform and Opening Up]. Beijing: People's Sports Publishing House of China.

GAS (Ed.) (2009). Pinbo licheng huihuang chengjiu: Xinzhongguo tiyu liushinian [A hardfighting journey and brilliant achievements: A sixty-year history of sport in new China] (comprehensive volume). Beijing: People's Publishing House.

Getz, D. (1991). Festival events and tourism. New York, NY: VanNostrand Reinhold.

Girginov, V., \& Hills, L. (2008). A sustainable sports legacy: Creating a link between the London Olympics and sports participation. International Journal of the History of Sport, 25(14), 2091-2116. doi:10.1080/09523360802439015

Giulianotti, R. (2015). The Beijing 2008 Olympics: Examining the Interrelations of China, Globalization, and Soft Power. European Review, 23(2), 286-296. doi:10.1017/S1062798714000684

Gold, J. R., \& Gold, M. M. (2008). Olympic cities: regeneration, city rebranding and changing urban agendas. Geography compass, 2(1), 300-318.

Goodwin, M., \& Grix, J. (2011). Bring structures back in: The 'Governance Narrative', the 'Decentre Approach' and 'Asymmetrical Network Governance' in the education and sport policy communities. Public Administration, 89(2), 537-556. doi:doi:10.1111/j.1467-9299.2011.01921.x

Gratton, C., \& Preuss, H. (2008). Maximizing Olympic impacts by building up legacies. The International Journal of the History of Sport, 25(14), 1922-1938. doi: $10.1080 / 09523360802439023$

$\mathrm{Gu}, \mathrm{W}$. (2011). Analysis on relationship between public recreational space construction of Beijing and residential happiness index. Journal of Sports and Science, 32(3), 46-48.

Hayhurst, L. M. C. (2009). The power to shape policy: charting sport for development and peace policy discourses. International Journal of Sport Policy and Politics, 1(2), 203227. doi:10.1080/19406940902950739

Hiller, H. H. (2006). Post-event outcomes and the post-modern turn: The Olympics and urban transformations. European Sport Management Quarterly, 6(4), 317-332.

Hogwood, B. W., \& Gunn, L. A. (1984). Policy analysis for the real world. Oxford: Oxford University Press.

Hong, F., \& Lu, Z. (2011). China. In M. Nicholson, R. Hoye, \& B. Houlihan (Eds.), Participation in Sport: International Policy Perspectives. London: Routledge.

Hu, R. X., \& Henry, I. (2016). The Development of the Olympic Narrative in Chinese Elite Sport Discourse from Its First Successful Olympic Bid to the Post-Beijing Games Era. The International Journal of the History of Sport, 33(12), 1427-1448. doi:10.1080/09523367.2017.1284818

Hu, X., \& Henry, I. (2017). Reform and maintenance of Juguo Tizhi: governmental management discourse of Chinese elite sport. European Sport Management Quarterly, 17(4), 531-553. doi:10.1080/16184742.2017.1304433 
IOC. (2014). Olympic Agenda 2020: 20+20 Recommendations. Retrieved from Lausanne: http://www.olympic.org/documents/olympic agenda 2020/olympic agenda 202020-20 recommendations-eng.pdf

IOC (2017). Legacy strategic approach: moving forward. Lausanne, Retrieved, October, 10, 2018 from https://www.olympic.org/ /media/Document\%20Library/OlympicOrg/Documents/Ol ympic-Legacy/IOC_Legacy_Strategy_Full_version.pdf?la=en

Kapareliotis, I., Panopoulos, A., \& Panigyrakis, G. G. (2010). The influence of the Olympic Games on Beijing consumers' perceptions of their city tourism development. Asia Pacific Journal of Marketing and Logistics, 22(1), 90-100. doi:https://doi.org/10.1108/13555851011013173

Kasimati, E., \& Dawson, P. (2009). Assessing the impact of the 2004 Olympic Games on the Greek economy: A small macroeconometric model. Economic Modelling, 26(1), 139146. doi: 10.1016/j.econmod.2008.06.006

Kassens-Noor, E., Wilson, M., Müller, S., Maharaj, B., \& Huntoon, L. (2015). Towards a mega-event legacy framework. Leisure Studies, 34(6), 665-671. doi:10.1080/02614367.2015.1035316

Kenyon, J. A., \& Bodet, G. (2018). Exploring the domestic relationship between mega-events and destination image: The image impact of hosting the 2012 Olympic Games for the city of London. Sport Management Review. 21(3), 232-249. doi:https://doi.org/10.1016/j.smr.2017.07.001

Kim, J., Rhee, S., Yu, J., Koo, K., \& Hong, J. (1989). Impact of the Seoul Olympic Games. Seoul: Korea Development Institution.

Kingdon, J. (1984). Agendas, alternatives, and public policies. Boston: Little Brown.

Koenigstorfer, J., Bocarro, J., Edwards, M. Jones, G., \& Preuss, H. (2017). The Legacy of Mega Sporting Events: A Systematic Review of Empirical Studies (1997-2016). European Association of Sport Management (conference proceedings).

Kong, F., \& Li, Y. (2005). The intension of Beijing Olympic Games cultural heritage and measure. Journal of Sports and Science, 26(4), 28-30. doi:https://doi.org/10.13598/j.issnl1004-4590.2005.04.008

Koutrou, N., \& Pappous, A. S. (2016). Towards an Olympic volunteering legacy: motivating volunteers to serve and remain - a case study of London 2012 Olympic Games volunteers. Voluntary Sector Review, 7(3), 269-291. doi: http://dx.doi.org/10.1332/096278916X14767760874050

Leopkey, B. (2009). The historical evolution of Olympic legacy. Retrieved from Ottawa.

Li, S., \& McCabe, S. (2013). Measuring the Socio-Economic Legacies of Mega-events: Concepts, Propositions and Indicators. International Journal of Tourism Research, 15(4), 388-402. doi:doi:10.1002/jtr.1885

Liu, B., Yao, Z., \& Lan, X. (2009). A study on TV communication of the 2008 Beijing Olympic Games. Journal of Capital Institute of Physical Education, 21(3), 284$288+321$.

Liu, F. (2009). Jishu Chuangxin: Zhongguo Pingpangqiu Yundong Fazhan de Bujie Dongli [Techenique innovation: The endless driving force of the development of Chinese table tennis]. In GAS (Ed.), 60 years of New China's sport (pp. 344-366). Beijing: People's Press.

London 2012 Olympic Games Bid Committee. (2005). Official bid document of the London 2012 Olympic Games Retrieved from London: LOCOG.

Madden, J. R., \& Crowe, M. (1998). Estimating the economic impact of the Sydney Olympic Games. 
Mahtani, K. R., Protheroe, J., Slight, S. P., Demarzo, M. M. P., Blakeman, T., Barton, C. A., . . . Roberts, N. (2013). Can the London 2012 Olympics 'inspire a generation' to do more physical or sporting activities? An overview of systematic reviews. $B M J$ open, 3(1). doi:10.1136/bmjopen-2012-002058

Mangan, J. A., \& Dyreson, M. (2013). Olympic Legacies: Intended and unintended: Political, cultural, economic and educational. Abingdon, Oxon: Routledge.

Manzenreiter, W. (2010). The Beijing Games in the Western Imagination of China: The Weak Power of Soft Power. Journal of Sport and Social Issues, 34(1), 29-48. doi:10.1177/0193723509358968

May, T. (1997). Social research: issues, methods and process (2nd ed.). Buckingham: Open University Press.

May, T. (2001). Social research: issues, methods and process (4th ed.). Maidenhead, Berks: Open University Press.

May, V. (1995). Environmental implications of the 1992 Winter Olympic Games. Tourism Management, 16(4), 269-275. doi:http://dx.doi.org/10.1016/0261-5177(95)00016-H

Minnaert, L. (2012). An Olympic legacy for all? The non-infrastructural outcomes of the Olympic Games for socially excluded groups (Atlanta 1996-Beijing 2008). Tourism Management, 33(2), 361-370. doi: 10.1016/j.tourman.2011.04.005

Nichols, G., \& Ralston, R. (2011). Social inclusion through volunteering: The legacy potential of the 2012 Olympic Games. Sociology, 45(5), 900-914. doi: $10.1177 / 0038038511413413$

Nye, J. S., \& Jr. (1990). Bound to lead: The changing nature of American power. New York: Basic Books.

Pang, Z. (2008). The Beijing Olympics and China's soft power. Brookings Institution.

Retrieved from www.brookings.edu/opinions/2008/0904_olympics

Party Literature Research Center of the CPC Central Committee (Ed.) (2004). Deng Xiaoping nianpu (A chronological biography of Deng Xiaoping). Beijing: Party Literature Research Center of the CPC Central Committee.

People.com.cn. (2000). A speech made by the Chairman, Jiang Zeminin, to the Chinese delegation of the XXVII Olympics. Retrieved from Beijing: http://www.people.com.cn/GB/channel1/10/20001003/258476.html

Pettigrew, A. M., Ferlie, E., \& McKee, L. (1992). Shaping Strategic Change: Making Change in Large Organizations : the Case of the National Health Service. London: Sage.

Pi, F. (2015). Study on the Influence of large-scale sports events on national soft power from the perspective of public diplomacy (Unpublished Ph.D. thesis). Shanghai International Studies University, China.

Preuss, H. (2004). The economics of staging the Olympics: A comparison of the games 19722008. Cheltenham: Edward Elgar Publishing.

Preuss, H. (2007). The conceptualisation and measurement of mega sport event legacies. Journal of Sport \& Tourism, 12(3-4), 207-228. doi:http://dx.doi.org/10.1080/14775080701736957

Preuss, H. (2015). A framework for identifying the legacies of a mega sport event. Leisure Studies, 1-22. doi: 10.1080/02614367.2014.994552

Preuss, H. (2018). Event legacy framework and measurement. International Journal of Sport Policy and Politics, 1-16. doi:10.1080/19406940.2018.1490336

Preuss, H., \& Alfs, C. (2011). Signaling through the 2008 Beijing Olympics-Using mega sport events to change the perception and image of the host. European Sport Management Quarterly, 11(1), 55-71. doi:10.1080/16184742.2010.537362 
Qiu, J. (2016). Dilemma of and solutions to the development of mass sport. China Sport Science, 36(7), 3-9.

Ren, H., Wang, F., \& Niu, J. (2006). The harmonious development of Beijing Olympic Games and Chinese sports. Sports Culture Guide, 4(2), 33-38.

Research Group of the Studies on Theory and Practice of Stepping from a Major Sports Nation to a Strong Sporting Nation (Ed.) (2010). Strategic Research on Strong Sporting Nation (1st ed.). Beijing: Renmin Tiyu Chubanshe [People' Sport Press].

Ritchie, J. R. B. (2000). Turning 16 days into 16 years through Olympic legacies. Event Management, 6(3), 155-165. doi:10.0000/096020197390239

Ryan, G., \& Bernard, R. (2003). Techniques to identify themes. Field methods, 15(1), 85109. doi: $10.1177 / 1525822 \times 02239569$

Sabatier, P. A. (1988). An Advocacy Coalition Framework of Policy Change and the Role of Policy-Oriented Learning Therein. Policy Sciences, 21(2/3), 129-168.

Sánchez, F., \& Broudehoux, A.-M. (2013). Mega-events and urban regeneration in Rio de Janeiro: planning in a state of emergency. International Journal of Urban Sustainable Development, 5(2), 132-153. doi:10.1080/19463138.2013.839450

Scheu, A., \& Preuss, H. (2017). The Legacy of the Olympic Games from1896 - 2016. A systematic review of academic publications. Working Paper Series - Mainzer Papers on Sport Economics \& Management, 14.

Smith, A., \& Fox, T. (2007). From 'event-led' to 'event-themed' regeneration: The 2002 Commonwealth Games legacy programme. Urban Studies, 44(5-6), 1125-1143. doi:10.1080/00420980701256039

Sports Ministry of China. (1995). The Outline of the Strategic Olympic Glory Plan: 1994 2000.

Stake, R. E. (1995). The art of case study research. Thousand Oaks, CA: Sage.

State Physical Culture and Sports Commission (SCPSC). (1958). Tiyu yundong shinian guihua [The Ten-Year plan for sports development] Beijing: SPCSC.

Sun, K., Liu, W., \& Mi, J. (2013). Mega-sport events and cointegration analysis of city economic growth-On the case of Beijing, Jinan and Guangzhou. Journal of Beijing Sport University, 36(4), 28-34.

The Chinese Olympic Committee. (2017). Olympic athletes' public service action in Yanqing. Retrieved from http://www.olympic.cn/emagzine/1702/2017/0221/143263.html

The State Council of the People's Republic of China. (1995). Quanmin jianshen jihua [national fitness programme]. Beijing: Internal Documents of CGAS.

The State Council of the People's Republic of China. (2000). Outline of the Sports Reform and Development in 2001-2010. Beijing: The State Council.

The State Council of the People's Republic of China. (2009). Quanmin jianshen jihua tiao li [Regulation on National Fitness] (No.560). Beijing: The State Council.

The State Council of the People's Republic of China. (2014). Opinions of the State Council on Accelerating the Development of Sports Industry and Promoting Sports Consumption (No.46 document). Beijing: State Council Retrieved from http://www.gov.cn/zhengce/content/2014-10/20/content_9152.htm.

The Tokyo Organising Commitee of the Olympic and Paralympic Games. (2015). Tokyo 2020 Games Foundation Plan. Retrieved from https://tokyo2020.org/en/games/plan/data/GFP-EN.pdf

Thomson, A., Schlenker, K., \& Schulenkorf, N. (2013). Conceptualizing sport event legacy. Event Management, 17(2), 111-122. doi:10.3727/152599513X13668224082260 
Tomlinson, A., \& Young, C. (2006). National identity and global sports events: Culture, politics, and spectacle in the Olympics and the Football World Cup. Albany: State University of New York Press.

Truno, E. (1995). Barcelona: City of sport. In M. de Moragas \& M. Botella (Eds.), The Keys to success: the social, sporting, economic and communications impact of Barcelona'92 (pp. 43-56). Barcelona: Servei de Publicacions de la UAB.

Wan, X. (2009). An empirical analysis of the reports of the Beijing Olympic Games and the building of China's national image. Journal of Capital Institute of Physical Education, 21(6), 694-697.

Wang, Z. (2012). An empirical study on the influence of the large-scale sports events on residents' happiness index in the hosting area. China Sport Science, 32(3), 28-38.

Weed, M. (2008). Olympic tourism. London: Butterworth-Heinemann.

Weed, M. (2015). Assessing gross and net impacts of mega events: The London legacy supraevaluation. Paper presented at the the European Sport Management Conference, Dublin.

Weed, M., Coren, E., Fiore, J., Wellard, I., Chatziefstathiou, D., Mansfield, L., \& Dowse, S. (2015). The Olympic Games and raising sport participation: a systematic review of evidence and an interrogation of policy for a demonstration effect. European Sport Management Quarterly, 15(2), 195-226. doi:10.1080/16184742.2014.998695

$\mathrm{Wu}, \mathrm{S} .(1999)$. The history of sport of the PRC. Beijing: China Books Press.

Xia, C., \& Tian, Y. (2010). Changes of sixty-years' strategies for sport development in China. Journal of Wuhan Institute of Physical Education, 44(1), 17-22.

Xiao, M. (2009). Historical evolution on mass sports policy in New China. China Sport Science, 29(44), 89-96.

Xinhuanet. (2008). Hu Jintao announces the opening of the 29th Olympic Games. Retrieved from http://2008.sina.com.cn/hx/other/2008-08-09/0623173144.shtml

Xu, G. (2008). Olympic dreams: China and sports 1985-2008. London: Harvard University Press.

Yang, C. (2015). Research on the relationship between sports lottery funded National Fitness Programme and public trust construction. In G. Liu \& Y. Yang (Eds.), China mass sport development report (2015) (pp. 223-231). Beijing: Social Science Academic Press.

Yang, H. (Ed.) (2012). Woguo aoyunhui beizhan cansai de lilun yu shijian [Theory and practice of China's Olympic preparation and participation] (Vol. 2). Beijing: China Legal Publishing House.

Yang, L. (2013). China's Growth Miracle: Past, Present, and Future. Retrieved from Geneva http://www.unrisd.org/80256B3C005BD6AB\%2F(httpAuxPages)\%2F2893F14F4199 8392C1257BC600385B21\%2F\$file\%2FChina's\%20growth\%20miracle\%200808.pdf

Yang, Y. (2005). Effects of the 2008 Olympic Games on Beijing's economy. China Sport Science, 25(8), 3-10.

Yi, J. D., \& Wang, D. J. (2016). Significance and value of Beijing 2022 Winter Olympic Games. Journal of Sports and Science, 37(5), 34-41.

Yin, R. K. (2014). Case study research: Design and methods (5th ed.). Thousand Oaks, CA: Sage.

Zhang, L., \& Zhao, S. X. (2009). City branding and the Olympic effect: A case study of Beijing. Cities, 26(5), 245-254. doi:http://dx.doi.org/10.1016/j.cities.2009.05.002

Zheng, J. (2015). A comparative analysis of the policy process of elite sport development in China and the UK (In relation to three Olympic sports of artistic gymnastics, swimming and cycling). (Unpublished Ph.D. thesis), Loughborough University, UK. 
Zheng, J., Chen, S., Tan, T. C., \& Houlihan, B. (2018). Sport policy in China. London: Routledge.

Zhou, Y., \& Ap, J. (2009). Residents' perceptions towards the impacts of the Beijing 2008 Olympic Games. Journal of Travel Research, 48(1), 78-91. doi:10.1177/0047287508328792

Zhou, Y., Wu, Y., Yang, L., Fu, L., He, K., Wang, S., . . Li, C. (2010). The impact of transportation control measures on emission reductions during the 2008 Olympic Games in Beijing, China. Atmospheric Environment, 44(3), 285-293. doi:http://dx.doi.org/10.1016/j.atmosenv.2009.10.040

Zhou, Y., Xin, L., \& Xiong, Y. (2006). Analysis on promotion of Olympic Games on economic growth of Beijing. China Sport Science, 26(3), 8-14. 
Table 1: Summary of coding

\begin{tabular}{lll}
\hline Initial codes & Secondary codes & Identified themes \\
\cline { 1 - 2 } Definitions & Policy focus & The values and roles of sport \\
\cline { 1 - 2 } Meanings & Missions and targets & \\
\cline { 1 - 2 } Process & Operating contexts & Mass sport development \\
\cline { 1 - 2 } & & \\
\hline Relevant passages of text & Olympics-related & \\
& elements & Sporting mega events policy \\
& & planning \\
& Organisational structure & \\
& and management & \\
& approaches &
\end{tabular}

Table 2: Policy attention in the three published Five-Year Plans.

\begin{tabular}{llll}
\hline Policy documents & $\begin{array}{l}\text { No of subsections } \\
\text { that are related to } \\
\text { mass sport }\end{array}$ & $\begin{array}{l}\text { No of subsections } \\
\text { that are related to } \\
\text { elite sport }\end{array}$ & $\begin{array}{l}\text { Number } \\
\text { differences } \\
\text { between the two } \\
\text { strands }\end{array}$ \\
\hline $\begin{array}{l}\text { The 11 } \\
\text { th Five-Year Plan }\end{array}$ & 8 & 13 & -5 \\
\hline $\begin{array}{l}\text { The 12 } \\
\text { (GAS } \text { Five-Year Plan } 2011 \text { a) }\end{array}$ & 10 & 14 & -4 \\
\hline $\begin{array}{l}\text { The 13 } \\
\text { (GAS Five-Year Plan } 2016)\end{array}$ & 7 & 6 & +1 \\
\hline
\end{tabular}


Table 3: 1994-2014 sports lottery public welfare fund spending details published by the GAS.

\begin{tabular}{|c|c|c|c|}
\hline Year & $\begin{array}{l}\text { Mass sport-related } \\
\text { activity spending }\end{array}$ & $\begin{array}{l}\text { Total Expenses } \\
\text { (unit: } \\
\text { 10000RMB) }\end{array}$ & $\begin{array}{l}\text { \% of sports lottery } \\
\text { money spent on } \\
\text { mass sport-related } \\
\text { activities }\end{array}$ \\
\hline 1994-1995 & - & - & - \\
\hline 1996 & 3357 & 7257 & 46.3 \\
\hline 1997 & 4820 & 7888 & 61.1 \\
\hline 1998 & 7423 & 12371 & 60.0 \\
\hline 1999 & 10265 & 14986 & 68.5 \\
\hline 2000 & 32159 & 47366 & 67.9 \\
\hline 2001 & 28069 & 39939 & 70.3 \\
\hline 2002 & 27000 & 40000 & 67.5 \\
\hline 2003 & 27000 & 40000 & 67.5 \\
\hline 2004 & 27100 & 42887 & 63.2 \\
\hline 2005 & 26680 & 48857 & 54.6 \\
\hline 2006 & 28400 & 60595 & 46.9 \\
\hline 2007 & 33152 & 69402 & 47.8 \\
\hline 2008 & 80363 & 157500 & 51.0 \\
\hline 2009 & 46685 & 70000 & 66.7 \\
\hline 2010 & 76910 & 105300 & 73.0 \\
\hline 2011 & 113170 & 143024 & 79.1 \\
\hline 2012 & 159084 & 201048 & 79.1 \\
\hline 2013 & 203969 & 230544 & 88.5 \\
\hline 2014 & 199366 & 224892 & 88.6 \\
\hline Total & 1134972 & 1563856 & $72.6 \%$ \\
\hline
\end{tabular}

Source: Adapted from (Yang, 2015). 


\section{Appendix: Key documents reviewed in the data analysis.}

\begin{tabular}{|c|c|c|c|}
\hline $\begin{array}{c}\text { Author(s) / } \\
\text { Organisation(s) }\end{array}$ & Year & Document Title & Publisher \\
\hline The State Council & 1995 & National Fitness Program [Quanmin Jianshen Jihua Gangyao] & $\begin{array}{l}\text { Beijing: The State } \\
\text { Council }\end{array}$ \\
\hline GAS & 1995 & $\begin{array}{l}\text { Development Outline of Sports Industry 1995-2010 [Tiyu Chanye Fazhan Gangyao } \\
\text { 1995-2010] }\end{array}$ & Beijing: GAS \\
\hline GAS & 1995 & $\begin{array}{l}\text { The Strategic Olympic Glory Plan 1994-2000 [1994-2000 Aoyun Zhengguang Jihua } \\
\text { Gangyao] }\end{array}$ & Beijing: GAS \\
\hline $\begin{array}{l}\text { GAS, Ministry of } \\
\text { Finance }\end{array}$ & 1998 & $\begin{array}{l}\text { Interim Procedures of Allocation and Use of Sports Lottery Public Welfare Funds [Tiyu } \\
\text { Caipiao Gongyijin Guanli Zanxing Banfa] }\end{array}$ & $\begin{array}{l}\text { Beijing: GAS, } \\
\text { Ministry of Finance }\end{array}$ \\
\hline The State Council & 2000 & $\begin{array}{l}\text { Outline of the Sports Reform and Development in 2001-2010 [2001-2010 Tiyu Gaige yu } \\
\text { Fazhan Gangyao] }\end{array}$ & $\begin{array}{l}\text { Beijing: The State } \\
\text { Council }\end{array}$ \\
\hline GAS & 2000 & $\begin{array}{l}\text { Interim Provisions of Sports Lottery and Mass Fitness Project Engineering [Zhongguo } \\
\text { Tiyu Caipiao Quanmin Jianshen Gongcheng Guanli Zanxing Guiding.] }\end{array}$ & Beijing: GAS \\
\hline $\mathrm{BOCOG}$ & 2001 & $\begin{array}{l}\text { Official bid document of the Beijing } 2008 \text { Olympic Games [Beijing } 2008 \text { Aoyunhui } \\
\text { Shenqing Baogao] }\end{array}$ & Beijing: BOCOG \\
\hline The State Council & 2002 & $\begin{array}{l}\text { Implementation Plan in the First Stage of the Second Project for Nationwide Fitness } \\
\text { Program outline [Quanmin Jianshen Jihua Gangyao Dier Gongcheng Diyi Jieduan } \\
\text { (2001-2005) Shishi Jihua] }\end{array}$ & $\begin{array}{l}\text { Beijing: The State } \\
\text { Council }\end{array}$ \\
\hline The State Council & 2002 & $\begin{array}{l}\text { Several Opinions of the Central Committee of the CPC and the State Council on Further } \\
\text { strengthening and improving the Sports Undertakings in the New Era. [Zhonggong } \\
\text { Zhongyang Guowuyuan Guanyu Jinyibu Jiaqiang he aijin } \\
\text { Xinshiqi Tiyu Gongzuo de Yijian] }\end{array}$ & $\begin{array}{l}\text { Beijing: The State } \\
\text { Council }\end{array}$ \\
\hline
\end{tabular}




\begin{tabular}{|c|c|c|c|}
\hline GAS & 2002 & $\begin{array}{l}\text { The Strategic Olympic Glory Plan 2001-2010 [2001-2010 Aoyun hengguang Jihua } \\
\text { Gangyao] }\end{array}$ & Beijing: GAS \\
\hline GAS & 2004 & $\begin{array}{l}\text { Notification of Further Strengrhening the Use and Management for Sports Lottery of } \\
\text { Mass Fitness Project Engineering [Guanyu Jinyibu Jiaqiang Yongyu Quanmin jianshen } \\
\text { de Tiyu caipiao Gongyijin shiyong Guanli de Tongzhi] }\end{array}$ & Beijing: GAS \\
\hline GAS & 2006 & Regulations of Sports Items Approval [Tiyu Xiangmu Lixiang Guanli Banfa] & Beijing: GAS \\
\hline The State Council & 2007 & $\begin{array}{l}\text { Several Opinions of the Central Committee of the CPC and the State Council on } \\
\text { Strenthening Adolescent Sports and Physical Health [Zhonggong Zhongyang } \\
\text { Guowuyuan Guanyu Jiaqiang Qingshaonian Tiyu Zengqiang Qingshaonian Tizhi de } \\
\text { Yijian Wenjian Quanwen] }\end{array}$ & $\begin{array}{l}\text { Beijing: The State } \\
\text { Council }\end{array}$ \\
\hline GAS & 2007 & The 11th Five-year Plan for the Development of Sport [Tiyu Shiye Shiyiwu Guihua] & Beijing: GAS \\
\hline GAS & 2008 & Olympic Glory Action Plan 2008 [2008 Aoyun Zhengguang Xingdong Jihua] & Beijing: GAS \\
\hline The State Council & 2009 & $\begin{array}{l}\text { Notification of the Responsibilities of the Inner Administrative Organization and Staffing } \\
\text { Regulations in GAS [Guowuyuan Bangongting Guanyu Yinfa Guojia Tiyu Zongju } \\
\text { Zhuyao Zhize Neishe Jigou he Renyuan Bianzhi Guiding de Tongzhi] }\end{array}$ & $\begin{array}{l}\text { Beijing: The State } \\
\text { Council }\end{array}$ \\
\hline The State Council & 2009 & Regulation on National Fitness [Quanmin Jianshen Tiaoli] & $\begin{array}{l}\text { Beijing: The State } \\
\text { Council }\end{array}$ \\
\hline The State Council & 2010 & $\begin{array}{l}\text { Several Opinions of the State Council on Accelerating the Sports Industry [Guowuyuan } \\
\text { Bangongting Guanyu Jiakuai Fazhan Tiyu Chanye de Zhidao Yijian] }\end{array}$ & $\begin{array}{l}\text { Beijing: The State } \\
\text { Council }\end{array}$ \\
\hline The State Council & 2011 & Nationwide Fitness Program 2011-2015 [Quanmin Jianshen Jihua 2011-2015] & $\begin{array}{l}\text { Beijing: The State } \\
\text { Council }\end{array}$ \\
\hline GAS & 2011 & The 12th Five-year Plan for the Development of Sport [Tiyu Shiye Shierwu Guihua] & Beijing: GAS \\
\hline GAS & 2011 & $\begin{array}{l}\text { The Strategic Olympic Glory Plan 2011-2020 [2011-2020 Aoyun hengguang Jihua } \\
\text { Gangyao] }\end{array}$ & Beijing: GAS \\
\hline
\end{tabular}




\begin{tabular}{|c|c|c|c|}
\hline Ministry of Finance & 2013 & $\begin{array}{l}\text { Centralized Sports Lottery Public Welfare Funds for Supporting Special Funds of Sports } \\
\text { [Zhongyang Jizhong Caipiao Gongyijin Zhichi Tiyu Shiye Zhuanxiang Zijin] }\end{array}$ & $\begin{array}{l}\text { Beijing: Ministry of } \\
\text { Finance }\end{array}$ \\
\hline The State Council & 2014 & $\begin{array}{l}\text { Opinions of the State Council on Accelerating the Development of Sports Industry and } \\
\text { Promoting Sports Consumption (No.46 document) [Guanyu Jiakuai Fazhan Tiyu Chanye } \\
\text { Cujin Tiyu Xiaofei de Ruogan Yijian] }\end{array}$ & $\begin{array}{l}\text { Beijing: The State } \\
\text { Council }\end{array}$ \\
\hline GAS & 2014 & $\begin{array}{l}\text { Comprehensive Evaluation System of Operations Management for Large-scaled Stadium } \\
\text { [Daxing Tiyu Changguan Yunying Guanli Zonghe Pingjia Tixi] }\end{array}$ & Beijing: GAS \\
\hline GAS & 2014 & $\begin{array}{l}\text { Fundamental Public Regulated Service of Large-scale Stadium [Daxing Tiyu } \\
\text { Changguan Jiben Gonggong Fuwu Guifan] }\end{array}$ & Beijing: GAS \\
\hline $\begin{array}{l}\text { GAS, Ministry of } \\
\text { Finance }\end{array}$ & 2015 & $\begin{array}{l}\text { Notification of Ministry of Finance and GAS for Launching Declaration Work of } \\
\text { Assistance Funds on Free or Low-cost Opening of Large-scale Stadium [Caizhengbu } \\
\text { Bangongting Guanyu Kaizhan 2015nian Daxing Tiyu Changguan Mianfei Dishoufei } \\
\text { Kaifang Buzhu Zijin Shenbao Gongzuo de Tongzhi] }\end{array}$ & $\begin{array}{l}\text { Beijing: GAS, } \\
\text { Ministry of } \\
\text { Finance }\end{array}$ \\
\hline BOCOG & 2015 & $\begin{array}{l}\text { Official bid document of the Beijing-Zhangjiakou } 2022 \text { Winter Olympic Games [Beijing- } \\
\text { Zhangjiakou } 2022 \text { Dongji Aoyunhui Shenqing Baogao] }\end{array}$ & Beijing: BOCOG \\
\hline GAS & 2016 & $\begin{array}{l}\text { The 13th Five-year Plan for the Development of Youth Sport [Qingshaonian Tiyu } \\
\text { Shisanwu Guihua] }\end{array}$ & Beijing: GAS \\
\hline GAS & 2016 & The 13th Five-year Plan for the Development of Sport [Tiyu Shiye Shisanwu Guihua] & Beijing: GAS \\
\hline GAS & 2016 & $\begin{array}{l}\text { The 13th Five-year Plan for the Development of Youth Sport [Jingii Tiyu Shisanwu } \\
\text { Guihua] }\end{array}$ & Beijing: GAS \\
\hline The State Council & 2016 & $\begin{array}{l}\text { Several Opinions on Accelerating Leisure Fitness Industry [Guanyu Jiakuai Fazhan } \\
\text { Jianshen Xiuxian Chanye de Zhidao Yijian] }\end{array}$ & $\begin{array}{l}\text { Beijing: The State } \\
\text { Council }\end{array}$ \\
\hline The State Council & 2016 & National Fitness Program 2016-2020 [Quanmin Jianshen Jihua 2016-2020] & $\begin{array}{l}\text { Beijing: The State } \\
\text { Council }\end{array}$ \\
\hline
\end{tabular}




\begin{tabular}{lclc}
\hline The State Council & 2016 & $\begin{array}{l}\text { Several Opinions of Promoting the Sports Tourism [Guanyu Dali Fazhan Yiyu Lvyou de } \\
\text { Zhido Yijian] }\end{array}$ & $\begin{array}{l}\text { Beijing: The State } \\
\text { Council }\end{array}$ \\
\hline GAS & 2016 & $\begin{array}{l}\text { The Plan for the Popularization of Mass Winter Sports 2016-2020 [Qunzhong Dongji } \\
\text { Yundong Tuiguang Puji Jihua 2016-2020] }\end{array}$ & Beijing: GAS \\
\hline $\begin{array}{l}\text { Beijing Municipal } \\
\text { Government }\end{array}$ & 2016 & $\begin{array}{l}\text { Several Opinions on Accelerating the Development of Winter Sports [Jiakuai Bingxue } \\
\text { Yundong Fazhan de Yijian] }\end{array}$ & $\begin{array}{l}\text { Beijing: Beijing } \\
\text { Municipal } \\
\text { Government }\end{array}$ \\
\hline
\end{tabular}

